War and the Destruction of the Russian Empire by Joshua Sanborn (2014), which does exactly that, and Shattering Empires: The Clash and Collapse of the Ottoman and Russian Empires 1908-1918 by Michael A. Reynolds (2011), which also discusses this issue, although without using the term "decolonization."

Another problematic issue is that Kumar does not pay proper attention to rupture and change in the nature of imperial projects in the twentieth century when he argues that the Weimar Republic "gave way to the same German Empire" (143), or when he treats the Russian Empire and the USSR largely as continuum without paying proper attention to the fact that it was exactly the mechanisms of center-periphery relations that had undergone a radical change in the Soviet Empire.

Engaging this literature would have given Kumar more "dialog space" and allowed him to develop and sharpen his argument. But it doesn't change the fact that this book is an important contribution to the new trend in the history of empires, and should become part of the reading list in many advanced courses in modern history.

AleXey Miller

European University in Saint-Petersburg

The Future of the Past: New Perspectives on Ukrainian History. Ed. Serhii Plokhy. Harvard Papers in Ukrainian Studies. Harvard University Press: Cambridge, Mass., 2016. x, 516 pp. Notes. Index. Maps. \$29.95, paper. doi: 10.1017/slr.2018.137

In 1995, the Slavic Review published the already classical yet still provocative article "Does Ukraine Have a History?" by Mark von Hagen, who then taught at Columbia University (Slavic Review, Vol. 54, No. 3 [Fall 1995]: 658-73). Professor von Hagen suggested several criteria for a historical field to be a legitimate academic enterprise. At the most general level, to satisfy the demand of academic legitimacy, a field of study, in our case the History of Ukraine, should boast "a written record of that experienced past that commands some widespread acceptance and authority in the international scholarly and political communities" (658). More particularly, in order for Ukraine "to have a history" in the eyes of outsiders, the subject of Ukrainian history should be present as a distinct field of studies in western academia; its practitioners should be non-Ukrainians (at least a significant number of them); a history of Ukraine should reflect Ukraine's historic diversity, fluidity of identities, and cultural permeability (667); and finally, the perceived "weaknesses" of Ukrainian history should be reinterpreted as its "strengths" (such as "the fluidity of frontiers, the permeability of cultures, [and] the historic multiethnic society"). If and when these conditions are met, Ukrainian history will then become "a very modern field of inquiry" and "a veritable laboratory for viewing several processes of state and nation building and for comparative history generally" (672).

The Future of the Past: New Perspectives on Ukrainian History, edited by Serhii Plokhy, provides strong evidence that during the last two decades von Hagen's main expectations have been largely realized. The volume is a product of several meetings of historians, but primarily the one that took place at Harvard University in October 2013. It comprehensively showcases all the most important historical issues and historiographical debates in the broadly-defined field of Ukrainian history. According to the volume's editor Serhii Plokhy, Professor of History at Harvard, the final product reflects "the state of Ukrainian historiography in light of its multiple and often 
conflicting orientations," as well as "the relation between Ukrainian historiography and the main trends in 'global' historiography" (2).

The book is split into four parts, each reflecting a particular set of historiographical issues. The part entitled "Towards a New Narrative" contains contributions grappling with the issue of the new narrative(s) of Ukrainian history. For example, Alfred Rieber, Professor-Emeritus at the University of Pennsylvania and Central European University, placed Ukraine within the "geo-cultural" context of five historical processes that shaped the Eurasian space, from the earliest recorded history to the ongoing period of the "revenge of the borderlands" (40). The famous Ukrainian historians Oleksii Tolochko and Georgiy Kasianov cast doubt at the very idea of a comprehensive national history, or what they call "the national master narrative."

The second part, "The Transnational Turn," looks at different issues pertaining to twentieth-century Ukraine through the prism of transnational approaches. The topics include the "heuristic potential" of Ukrainian history for modern European history (Italian historian Andrea Graziosi); the impact of the world wars and Stalinist policies on Ukraine's demographics (George O. Liber, University of Alabama); colonialist interpretations of Bolshevik, interwar Polish, and Nazi German policies towards Ukraine (Mark von Hagen, Arizona State University); Ukraine's place in Eurasian history in the twentieth century (Hiroaki Kuromiya, Indiana University); the transnational context of Ukrainian cartography in the early decades of the twentieth century (Steven Seegel, University of Northern Colorado); the history of Jews in Ukraine in Eurasian context (Yohanan Petrovsky-Shtern, Northwestern University); and the project of modern Ukrainian culture in 1920s Soviet Ukraine (Mayhill Fowler, Stetson University).

The third part, entitled "The Return of the Region," is devoted to the studies of Ukraine's historical regions, often within wider political, economic, and cultural contexts of modern eastern Europe. Larry Wolff of New York University examines the idea of Galicia for local Poles and Ukrainians and the collapse of that idea after 1918. Iryna Vushko of Hunter College writes about the contemporary historiography of Austrian Galicia. Faith Hillis of the University of Chicago focuses on Right-Bank Ukraine as a region that gave rise to an aggressive brand of Russian nationalism in the late nineteenth and early twentieth centuries. Another side of the same region-its role for the nascent Ukrainian movement-is explored by Heather Coleman (University of Alberta). Another scholar from the same university, Zenon Kohut, analyzes recent Ukrainian publications on Cossack elites. Serhii Plokhy of Harvard University describes a groundbreaking project recently launched by Harvard Ukrainian Research Institute: the Digital Atlas of the Holodomor (the Great Famine in Ukraine of 1932-33) that features detailed regional maps of famine intensity, collectivization, and direct famine losses.

Finally, the fourth part, "Representations of the Past," contains contributions from four scholars: on the experiences of teaching Ukrainian history in North America and Russia (Paul Robert Magocsi, University of Toronto and Tatiana Tairova-Yakovleva, St Petersburg State University, respectively); on Soviet historical myths in post-Soviet Ukraine (Volodymyr Kravchenko, University of Alberta); and on the Ukrainian mass media and historical memory in contemporary Ukraine (Marta Dyczok, University of Western Ontario).

Judging by the volume's diverse contributions, one can give a positive answer to Mark von Hagen's seminal question: Ukraine does have a history (or rather histories). What is more, there are a growing number of historians of non-Ukrainian descent across North America who write on Ukrainian topics or teach Ukraine-related courses. Many of these historians have contributed to the volume under review. Perhaps an added value of the essays collected by Serhii Plokhy is that they might help us better 
understand the current Ukrainian-Russian conflict, in which history has played an important role. Can history be blamed for the worst international crisis in east-west relations since the end of the Cold War?

\author{
SERHIY BILENKY \\ University of Toronto
}

\title{
Religion in the Mirror of Law: Eastern European Perspectives from the Early \\ Modern Period to 1939. Ed. Yvonne Kleinmann, Stephan Stach, and Tracie L. Wilson. Studien zur europäischen Rechtsgeschichte no. 280. Frankfurt am Main: Vittorio Klostermann GmbH, 2016. xxvii, 350 pp. Notes. Photographs. Maps. $€ 49.00$, paper.
}

doi: 10.1017/slr.2018.138

A collection of scholarly papers encompassing the entire territory of the former Polish-Lithuanian Commonwealth over a period spanning more than four centuries, Religion in the Mirror of Law nevertheless achieves an admirable focus on the "interconnections of religion and law" (ix). Considering the various and changing political, social, and cultural conditions over space and time, this collection of fifteen articles still works as a whole to assess "the legal tools that formed the basis for cooperation, negotiation, mediation, and compromise between different religious communities and between individuals of different confessions" (ix), a welcome shift from the usual approach of assessing interreligious conflict or dissonance.

The anthology derives from papers presented at the 2010 international and interdisciplinary conference "Religion in the Mirror of Law: Research on Early Modern Poland-Lithuania and its Successor States in the $19^{\text {th }}$ and Early $20^{\text {th }}$ Centuries" held in L'viv at the Center for Urban History of East-Central Europe, spearheaded by the research group on law in ethno-religiously mixed societies of Poland-Lithuania at the Institute for Slavic Studies at Leipzig University (vii). The scholars involved followed the anthropological perspective of Lawrence Rosen that law cannot be separated from culture and that it should be seen as "a framework for ordering relationships," as well as the approach used in Law and Society Studies that stresses "the links between law, institutions, and the public sphere" (xii).

That eleven of fifteen articles discuss legal aspects and ramifications of Jewish communities in this geographic region reveals the extent to which their coexistence with the dominant Christian societies comprised perhaps the most intriguing aspect of legal life in the former Commonwealth-and certainly one rich in sources and circumstances ripe for study. Additionally, three articles discuss issues pertaining to Uniates, or Greek Catholics, and one addresses the role of the Polish Institute for Nationality Research in the 1920s and 1930s. Orthodox, Protestant, and Muslim experiences are not represented in this collection. The editors have distributed the articles into four conceptual parts: "Imagining Law-Imagining Society,” providing interdisciplinary approaches to a more flexible view of law; "Shifts in Political Rule and the Reorganization of Law," addressing ways religious communities mediated between the state and national groups; "Competing Laws-Competing Loyalties," exploring "legal pluralism" in situations of changed political context; and "EthnoReligious Coexistence in Legal Norm and Practice," with a focus on Jewish-Christian coexistence. The publisher is to be commended for allowing lengthy and informative footnotes throughout.

Dominating the volume, the articles regarding the Jewish experience offer fresh perspectives on their legal place within different Christian societies and political 